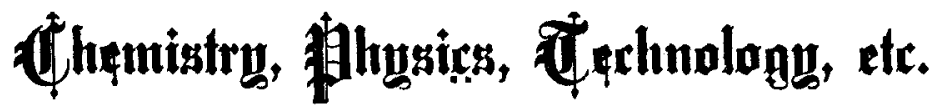

INFUSORIAL EARTH AND ITS USES.

\author{
By Dr. W. H. WAHL.*
}

[From the Quarterly Journal of Science, for July, 1876.]

Geologists have long since established, beyond peradventure, the fact that there are rocks in the interior of continents, at various depths in the earth, and at great heights above the sea, which are almost entirely made up of the remains of what were once living organisms. Such rock-masses, says Lyell, way be compared with modern oyster beds and coral reefs, and, like them, their rate of increase múst have been extremely gradual. But there are a variety of mineral deposits that are now proved to have been derived from plants and animals, of which the organic origin was not suspected even by naturalists. Great surprise was therefore manifested when the late Prof. Ehrenberg announced the discovery that a certain kind of siliceous stone, called tripoli, was entirely composed of the remains of countless millions of extremely minute organic beings. This observation of the famous German microscopist speedily led to the discovery of the fact that deposits of this character were quite abundant, and that they were even being formed at the present time over extended areas. The minute organisms, whose skeletons make up the bulk of the deposits, which are now known under the name of infusorial earth, have been shown to inhabit the ocean in inconceivable numbers, giving rise to the luminosity of the waters, which has been the subject of much discussion, and flourishing in almost every place where water stands for several months of the year. Their indestructible shells are therefore to be found in greater or less quantity in the sedimentary deposits of all our bogs, ponds, and slow streams. They are found in great abundance beneath peat bogs, where they constitute strata, often many feet in thickness and of great extent, almost entirely composed of the siliceous carapaces of

* Editor Polytechnic Review, Phila. 
organic beings, so inconceivably minute that millions of their remains are found in a single inch. Ehrenberg estimates that about 18,000 cubic feet of these siliceous organisms accumulate annually in the harbor of Wismar, in the Baltic. He has, furthermore, demonstrated that they accumulate in the beds of American and other seas, lakes and rivers.

The deep sea soundings which have lately been conducted in various quarters of the world, and have attracted much popular interest, have shown, likewise, that the impalpable mud or ooze, which is accumulating at great depth in the bed of the Atlantic'sd other oceans, is made up almost entirely of the mineral skeletons of certain extremely minute organisms. Of these shells, some are calcareous, and appear to be identical with the organisms which abound in the chalk of Europe-the chalk, indeed, is largely made up of such organic remains-while others are siliceous. One of these deposits in the North Atlantic has been traced over a distance of thirteen hundred miles in breadth, and not less than six hundred miles in length.

In peat bogs, swamps, and the like, both of modern and ancient origin, there are often found layers, at times many feet in thickness, and of considerable extent, of a white siliceous paste, which is found beneath the microscope to be made up wholly of the remains of these minute organisms. These deposits, with which this article is chiefly concerned, are designated by geologists with the name of infusorial earth. The substance of which they are composed has generally, when dry, the appearance and consistence of friable chalk, and the remains of which it is made up, and which were formerly referred to microscopic infusoria, are now generally held to be plants, called by naturalists diatomacece. The remains of these diatomaceæ are of pure silex, and their shapes, as seen beneath the microscope, are various, and form objects, often of extreme beauty. These forms are very marked and constant in particular genera and species, of which many hundreds have been described and classified by Ehrenberg, Bailey, and others, and while many of the fossil forms are identical with living species, others are allied to them; and the so-called infusorial beds are sometimes of marine and sometimes of fresh water origin. The infusorial earth may readily be distinguished from the several calcareous and clayey deposits which it resembles in appearance, by the fact that it does not effervesce in acids, and its ready solubility 
in solution of caustic soda or potash. It has long been well known in the arts as a powder for polishing stones and metals. At Bilin, in Bohemia, which is famous for its occurrence, there is a single stratum of this material, not less in some places than 18 feet in thickness, and extending over a large area. This stone, when seen beneath the microscope, is found to consist of the siliceous plates or frustules of the above mentioned diatomaceæ, united together without visible cement, and so inconceivably minute are the particles of which it is composed that, according to Ehrenberg's statement, a single cubic inch, which weighs about 220 grains, contains about $41,000,000,000$ of individuals, and a single grain no less than 187,000,000. Other deposits of infusorial earth (kieselguhr), scarcely less extensive, occur in Germany, at Berlin, and at Planitz, in Saxony. It is found near Lüneburg, in a stratum nearly 28 feet in thickness, and again at Kliecken, near Dessau, and in the vicinity of Cassel. In England'deposits of considerable magnitude have been found in Surrey, at the base of the chalk hills, and elsewhere. In Ireland there is a celebrated stratum on the banks of the River Bann, in the county of Down, and which, from being in much request for polishing plate, is locally known as Lord Roden's plate powder; another bed is found at the base of the Mourne Mountains, in the same county. In Lapland a similar earth is met with, which in times of scarcity, it is said, is mixed by the inhabitants with the ground bark of trees and used for food. The edible earth of Lillhaggsjon, in Sweden, is of the same nature. The infusorial earth is found in quantity in the Isle of France and at San Fiora, in Tuscany, and deposits of various thicknesses have been detected in Africa (the tripoli of commerce is an infusorial earth that has long been exported from the country whose name it bears), Asia, Australia, and New Zealand. In America it has been found in a great number of localities, and occasionally in enormous quantities. of this nature are the beds of white earth along the banks of the Amazon, in Brazil, and used occasionally as food (?) by the native inhabitants. They have been detected also in Newfoundland and Labrador. In the United States perhaps the most remarkable deposit is that upon which the City of Richmond, Va., is built; this deposit is, in places, over 20 feet in thickness, and has been traced by Prof. W. B. Rogers, who was the first to point out its nature, from Herring's Bay, on the Chesapeake, Md., to Petersburg, Va.,

Whole No. Vez. CII.-(Thrrd Shries, Vol, lxxii.) 
and beyond. At Petersburg the stratum is 30 feet in thickness. Beds of the same character and of some magnitude have likewise been found in California, Oregon, and other points on the Pacific, and at West Point, N.Y.; while of less importance are the infusorial beds at Wrentham and Andover, Mass., Smithfield, R.I., Stratford, Conn., and other localities too numerops to mention.

An interesting occurrence of this nature is the deposit of infusorial earth at Drakeville, Morris County, New Jersey, and which, through the instrumentality of the writer and others, was first brought into general public notice about three years ago. The bed in question is on the property of the late Frederick S. Cook, and is located at the foot of Schooley's Mountain. The annual report of Prof. George H. Cook, State Geologist of New Jersey for 1874, contained a descriptive article in reference thereto, from which we obtain the following statements concerning its probable extent, etc. :

"It has been known as a white earth or marl for a long time, and some years since was dug out and spread upon the soil as a manure; it had also been observed to possess remarkable excellence for scouring silver. The establishment of a manufactory for making nitroglycerine and giant powder at McCainsville, near Drakeville, in which infusorial earth imported from Germany was used, led to an examination of this deposit, when it was found to be the same material with that they were bringing from Europe. The deposit occurs in a depression of the surface just at the foot of the mountain (Schooley's). The swale appears to be occupied in its lowest part by a common swamp of low bushes, growing in wet black earth; but by digging in the black earth it is found to be only about a foot thick, and underneath it is the infusorial earth. The extent of the black ground is about 540 feet in length by 200 feet in breadth, and 100 yards north-east is another but much smaller deposit. A trial pit sunk in the middle of the swale showed a thickness of 12 inches of black earth, 8 inches of very light infusorial earth, and 12 inches or more of a much denser infusorial earth. The lower part is said to be 3 feet thick, but I only examined the upper foot of it."

The report continues: "There is little doubt that other deposits will be found in the small ponds and swamps in this gneiss region, and those interested will do well to make search for it in any of the swales where these little swamps occur. It can be easily reached by digging, and when found can be distinguished from any other white 
earth by its not effervescing with acids as white marl does, by its not becoming plastic when wet, as white clay does, and by its dissolving almost entirely in a strong boiling hot solution of washing soda.

" The importance of this material will be appreciated when it is stated that the manufacture of dynamite, or giant powder, at Drakeville, has reached 50,000 pounds a month. There are different grades of dynamite, but some of it contains 25 per cent. of infusorial earth."

An analysis of an average dried sample of the Drakeville deposit yielded the writer 47.12 per cent. of soluble silica.

Concerning the application of this curious substance in the useful arts quite a chapter might be written. During the past few years it has attracted the special attention of practical men, and so many and various have been the uses for which it has been suggested that their

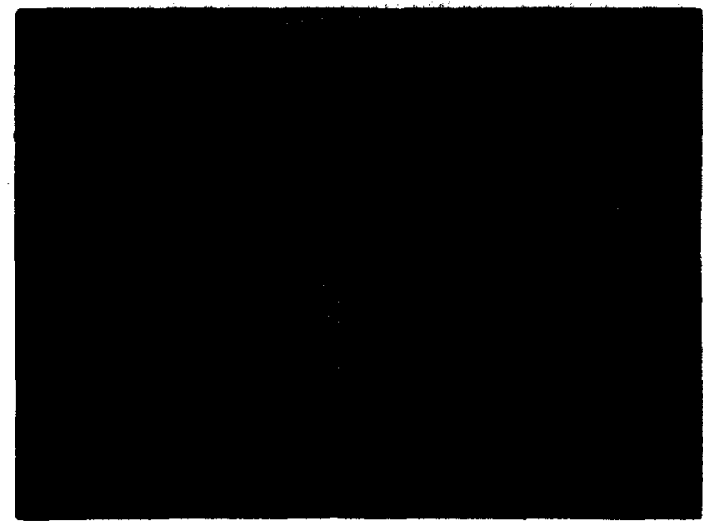

FORMS OF DIATOMS FROM THE RICHMOND DEPOSITS.

bare enumeration may well excite surprise. At least one very important industry of recent origin has been practically created by it, and its employment in others is steadily growing in extent and importance. A summary of the subject in its technical aspects, with brief comments upon the more important items, is given in what follows.

The most popularly known, and perhaps the earliest application of the diatomaceous earth, is its utilization as a polishing agent for stone and metals. For this purpose, when carefully freed from grit and other impurities, its considerable hardness and its wonderfully fine state of division fit it most admirably. It may be applied wet or dry. It is well known in this connection under the nawe of tripoli, 
so called from the locality whence it was originally brought. Under the name of "electro-silicon," "magic-brilliant," and other trade designations, the diatomaceous earth from Nevada and other localities has been extensively introduced as a polish for gold, silver, and plated ware, for which-as for tin, Britannia ware, and other metals used in the household-its wide populatity is the best proof of its excellence.

Being a very poor conductor of heat, it has been suggested and applied for surrounding ice, beer and ale cellars, fire-proof safes, steam-boilers, powder-magazines, refrigerators, etc. The results òf certain experiments lately made by Refart and Co., of Braunschweig, to ascertain how this material compared with other substances generally employed for the purpose, are highly favorable to the merits of infusorial earth for this application.

Without entering into the mechanical details of the apparatus employed in these trials, it will suffice to state that in the time required to melt 100 parts (by weight) of ice surrounded by the siliceous earth, 235 parts of ice were melted in a cylinder surrounded with an equally thick layer of dry, light garden earth. Moist earth, and moist materials generally, gave still more unfavorable results. Again, for every 100 part 3 of ice melted when protected by the infusorial earth, 142 parts of ice protected by dry, sifted coal ashes, were melted. The results obtained with flax-shives were about the same as with the infusorial earth. These trials demonstrated that infusorial silica and flax-shives offer the greatest amount of resistance to. the transmission of heat; that dry coal-ashes are far less efficient, and moist ashes still more so; and finally that earth, as compared with these, is very inferior as a non-conductor. The use of the infusorial earth is therefore highly recommended for filling in between the walls, and for covering the mason work in ice-cellars. For this purpose the following additional advantages are urged in favor of this substance, viz.:-It is extremely light,--being nearly five times as light as dry earth, and about half the weight of dry coal ashes,--and it is not combustible, remaining unaffected in the hottest fire. These properties, to quote from the published account of the above trials, "render this substance preferable to flax-shives, tan-bark, peat, sawdust, and similar materials, which are about equal to it in non-conducting quality, but which are combustible, and when kept for some time rot or moulder, shrink and settle, and might under some circumstances, take fire spontaneously" (sic '). 
The infusorial earth, it is further claimed, will be found highly useful in fire-proof safes, as a surrounding for powder-magazines on shipboard, for covering steam-pipes and boilers, and for all similar purposes. Reference is made in some of the encyclopædias (vide "American Encyclopædia," iii, 268) to what are termed floating bricks, which, according to account, are made of infusorial earth, and are named in virtue of their power of floating upon water. Clay is sometimes added to the silica to assist in binding the material together. Such bricks, we are told, were made in ancient times, and were described by Posidonius and Strabo, and particularly commended by Vitruvius, Pollio, and Pliny. In 1791 they were again brought into notice by Giovanni Fabroni, in Tuscany, who, after many trials, succeeded in making bricks which would float upon water. Their strength was but little inferior to that of ordinary bricks; they are remarkable not only for extreme lightness, but also for their infusibility, and for being very poor conductors of heat; they may be held at one end while the other is red-hot. As an experiment, Fabroni constructed the powder-magazine of a wooden ship with these bricks; the vessel being set on fire, sank without explosion of the powder. In 1832 Count de Nantes, and Fournet, a mining engineer, used them in constructing powder-magazines and other parts of ships, thus lessening danger from fire. From an earlier source (" Encyclopædia Americana," ii, 265) we are informed that these floating bricks, made of agaric mineral or fossil farina,-infusorial earth, - - have been found, on account of their infusibility at the highest temperatures, to be extremely useful in constructing reverberatory furnaces, pyrometers, and magazines of combustible materials, while their lightness and non-conducting qualities render them particularly useful for the construction of powder-magazines on board of ships.

In agriculture, the use of the infusorial earth has been suggested as a manure for lands poor in silica, which substance enters importantly into the constitution of the stalks and outer coverings of cereals. Quite an animated controversy, indeed, has of late sprung up as to the merits of infusorial silica as a component of fertilizers, an idea which forms the essential feature of a patent lately issued to Messrs. N. and G. Popplein, Jun., of Baltimore. It would be foreign to the purpose of this sketch to enter into a discussion of the merits of this controversy, involving as it does the introduction of certain debatable questions in agricultural chemistry; but the ideas of the Messrs. 
Popplein have aroused on the one hand such warm championship, and on the other such opposition, that a concise statement of the points in dispute may not be amiss.

The manufacturers before named, proceeding from the well-known fact that the relative quantity of silica in the ash of the cereals is greatly in excess of what is required forthe normal combination with the bases (potash, soda, etc.) found therein, claim that in the ordinary course of things it is impossible for Nature to furnish to cultivated lands for successive years the proper amount of silica in assimilable form for the plant, inasmuch as the liberation of this substance by the chemical decomposition of the mineral matters of the soil containing it, goes on so slowly as to render doubtful the production in many years of the amount required for a single crop. In proof of this assertion they refer to the great reduction in the yield of the wheat crop, since farmers began years ago to sell the straw of the crop that formerly was returned to the soil. For this, and other reasons less obvious, their attention was attracted to the importance of incorporating silica into commercial fertilizers-one difficulty remained to be overcome, namely, the discovery of a form of the silica - which should be assimilable by the plant. This they claim to have found in the infusorial earth,-in which the silica is in an inconceivably minute state of division,---the result of their consideration being the production of a so-called " silicated superphosphate of lime," a superphosphate with which the infusorial earth is intimately incorporated. The argument urging the importance of an abundant supply of silicic acid in available form, as an absolute necessity for the proper nutrition of cereals, is not disputed; and the manufacturers, to demonstrate the availability of the silica in the form in which they employ it, affirm that they have succeeded in proving the highly interesting and novel fact that the very minute skeletons or shells of which the infusorial earth is mainly composed are carried up as such into the body of the plant itself. Upon this point the following gleanings from an investigation conducted by Prof. P. B. Wilson will be read with interest :-

This chemist subjected to a microscopical examination the straw from the wheat-fields of Col. J. B. Kunkel, of Frederick County, Maryland, which had been fertilized by the silicated phosphate, his purpose being to make " a more complete investigation into the siliceous structure of the stalk, in determining whether the infusoria 
passed directly as such into the sap-cells, to be carried forward by capillary force, and to finally assume their functions, - the formation of the epidermal shield for giving strength to the straw, to withstand the destructive force of high winds and beating rains, as well as a protection against the attacks of parasites."

"In making these investigations thorough precautions were observed, to cleanse the straw from all accidental impurities by washing and gentle friction, not sufficient, however, to destroy the epidermis. The organic matter was then removed by the prescribed methods, aided by my own experience.

"My labors," he continues, "have been amply rewarded by one of the most enchanting views that has ever fallen to my lot to behold through twenty years of varied scientific investigations. When the epidermal siliceous coating was adjusted upon the field of the microscope, some thirty-six forms of the Diatomaceæ, which $I$ have carefully sketched, were observed (see engraving, magnified 300 diameters) where perfect disintegration hăs been produced. When the structure to a great extent is retained, a marvelous interlacing of these forms presents itself sometimes side by side, at other times overlapping."

From this very interesting observation, Prof. Wilson advances a number of inferences, which, although the writer is not prepared to accept in full, are of sufficient interest to warrant their reproduction. $\mathrm{He}$ affirms that his investigation "overthrows all theories that have ever been advanced, that silica enters into plant structure in combination with the alkalies, the alkaline earths, or the earths proper. Chemical investigation led me to this conclusion some months since, now confirmed by that of the microscope.

"My mind was particularly impressed with the absence of the disc-like form, the Actinocyclus ehrenbergii and the Actinoptychus undulatus in their perfect state in the straw, while the other forms are common both to the infusorial earth and the wheat. My conclusions are that the varieties mentioned are too large to enter the root capillaries, for on the field of the microscope they have three to four times the magnitude of the others. This I will fully investigate during the coming summer, by making accurate measurements of rootlets and diatoms, when I will be able to obtain stalks of wheat as grown in the fields, preferring this mode of investigation to pot culture, to disarm controversy, and to divest the investigation of all semblance of laboratory experiment. 
Forms of Diatoms found in Col. Kunkel's Straw. MAGNIFIED 300 DJAMETERS.

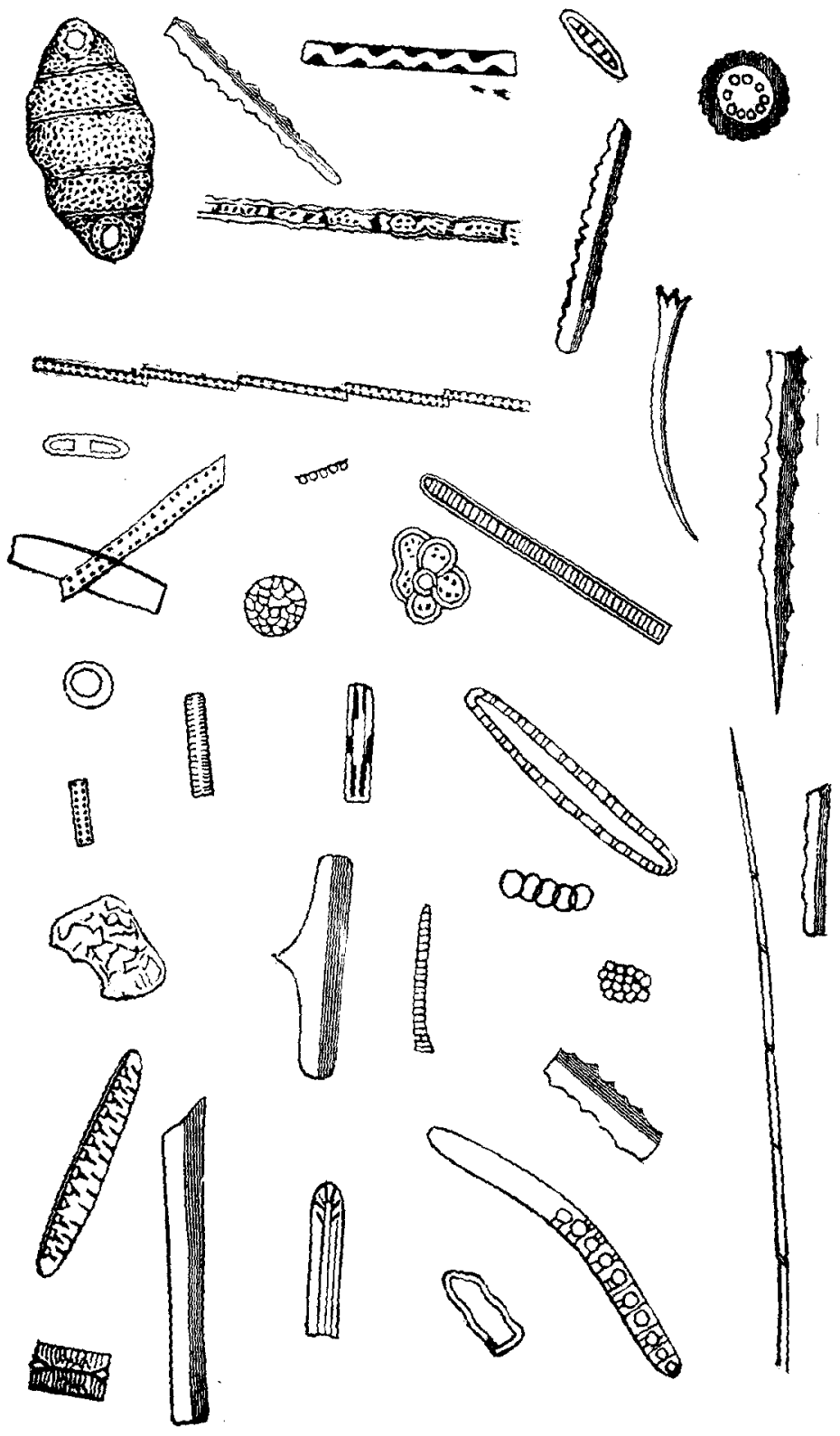


"I have examined various specimens of wheat straw taken at random from the market, but have failed to find a single diatom. This to a certain extent surprised me, when taking into consideration that they are found to a limited extent in Peruvian guano. The inference to be drawn is, that the soil was not fertilized by any material into which it entered as a constituent. I mention this to guide others who may make subsequent investigations from falling into error, in case occasional Diatomaceæ are observed, as being derived from other sources than the infusorial deposits.

"These microscopic investigations show the absence of other forms of silica, that is, in granular particles in the (Kunkel) straw, they being entirely replaced by diatoms. This leads to the conclusion, that the diatom is the more acceptable for assimilation, and when sufficient infusorial remains are present, replaces any other divided form of silica. I have previously attempted to substitute silica for diatoms, as obtained from the decomposition of slags from iron furnaces, but we have failed to derive any satisfactory results. This is due to its combination as a silicate; and when liberated by stronger acids, it agglutinates into masses too hard and large to be absorbed by the plant."

Prof. Wilson concludes his report in the following glowing terms: "I look upon this application of vegetable silica to fertilizing purposes as the most important adaptation of matter for the reproduction of vegetation that has ever been discovered. It is the first step in a new direction, rationally conceived and judiciously carried out. A new impetus will be given to the study of plant physiology, which will demonstrate that more than a heterogeneous mixture of elementary bodies and their compounds are required for the production of the crops beneficial to the requirements of man."

With regard to the foregoing statements and inferences of Prof. Wilson, while not attempting to undervalue their great interest and possible entire accuracy, the writer would remark that the demonstration of the presence of the infusorial forms in the structure of the wheat stalks proves simply that these bodies are sufficiently minute to enter the root capillaries and pass in to the sap-cells of the plant-nothing more. It may possibly be that, once having entered the body of the plant, they are assimilated, and made to subserve to the function of giving strength to the stalk; or, as appears to the writer equally plausible, they may simply act as so many minute 
mechanical impurities drawn into the circulation of the plant, and, effecting a lodgment wherever they chance, clog up the passages, and thus actually obstruct rather than serve the process of nutrition. To follow the bistory of one of these forms in a living plant under the microscope, and observe its gradual dissolution, would afford the only method of positively proving the truth or falsity of either of the explanations that have been presented. While not presuming to decide so doubtful a question, it is very reasonable to believe that much of the silica of the so-called silicated superphosphate is made "available" as plant-food in solution as an alkaline salt, in whichcondition its assimilation by the plant presents no difficulties to the understanding. Dr. Wolf, the excellent State Chemist of Delaware, has kindly furnished the writer the following record of an analysis of the " silicated superphosphate," viz. :-

Soluble Phosphoric A cid,

Precipitated Phosphoric Acid,

Insoluble Phosphoric Acid,

Silica,

Sulphate of Potassa,
$5 \cdot 855$ per cent.

$3 \cdot 327$ " 6

trace.

$20 \cdot 568$

$6 \cdot 173$

According to the Messrs. Popplein's published formula, the net ton of their "silicated superphosphate" contains :-

Infusorial Earth,

Dissolved Bone,

Potash Salts, .
800 lbs.

800 "6

400 “

As an absorbent and carrier of liquids of various kinds, and especially as a carrier of nitro-glycerin, the infusorial earth has been found to be most excellently adapted. It takes up from three to five times its weight of water, oil, nitro-glycerin, etc. It would doubtless prove equally valuable as a carrier of carbolic acid and other disinfectants, as a disinfecting powder, and has possibly already found application for this purpose.

In order to bring nitro-glycerin within the range of articles of transport, Nobel, who first demonstrated its value in the arts, devised the production of a powder now so extensively employed under the name of dynamite, in which the explosive oil is simply carried by the inert, pulverulent siliceous earth. The process of the preparation of dynamite may be described as follows:-

The infusorial earth must first be freed from water, organic substances, and mechanical impurities (sand, etc.). The first two are 
removed by calcining at a red heat in an oven with several shelves, one above the other, on which the earth is placed and slowly pushed from the upper to the lower. The organic matter, which is considered dangerous to the stability of the dynamite, is thus burned out. It is then pressed with hard rollers and sifted, which separates it from the larger particles and grit. It is now ready for use.

Fifty pounds of infusorial earth are put into flat wooden tanks and covered with 150 pounds of nitro-glycerin, when the workmen mix them with the naked hand. Gloves of india-rubber were at first. provided, but the workmen preferred to knead the mixture with the free hands. In half an hour the incorporation of the oil with the earth is complete, and the dynamite is ready for filling in the cartridge moulds. The cartridges are simple cylinders, protected by parchment paper. If ordinary paper is used the oil soaks into it, and there is great danger of premature explosion. Dynamite is a brownish gray, sometimes reddish, inodorous, pasty, greasy mass, having the specific gravity of $1 \cdot 6$. When ignited by an ordinary flame, it burns up quickly without detonation, and must therefore be fired with a patent exploder containing fulminate of silver inclosed in a copper capsule. It requires a heavy blow of a hammer on an anvil to explode it, and even then only the portions struck are fired. In this respect it presents great advantages over nitro-glycerin, which is easily exploded by percussion. On the other hand, the wood of the boxes in which dynamite is packed becomes by slow degrees impregnated with nitro-glycerin, and forms a most dangerously explosive material, which may give rise to serious accidents in warehouses where it is stored. As long as the nitro-glycerin is confined in the infusorial silica there appears to be very little danger, but the escape of a few drops of the oil may be the source of great mischief. The force exerted by the dynamite is much greater than that of gunpowder, and under the name of giant powder it has been largely employed in the mines of California. Other explosives, such as dualine and lithofracteur, may be said to be varieties of dynamite, having nitro-glycerin for their base, and using saw-dust or some other substance as an absorbent. All of them are powerful explosives, and must be handled with care.

For the preparation of cements and of artificial stone, a number of processes have been devised, in which infusorial earth plays a prominent part, viz.: Equal parts of infusorial silica and litharge, and 
one-half part of slaked lime, stirred into a paste in linseed oil, is affirmed to become as hard as sandstone on setting, and is recommended as an excellent compound for cementing stone, metal, and wood. The following recips, again, is pronounced to be serviceable for the production of an artificial stone for art objects. For this purpose the infusorial earth is intimately mixed with well pulverized, freshly burned lime, in the proportion of from three to six parts of the former to one of the latter. The mixture is then pressed into moulds under an addition of a very slight quantity of water. The resulting product, a silicate of lime, is formed with the evolution of . considerable heat. The objects produced ultimately attain great hardness; they are perfectly water-proof, and may readily be colored with any color used in stereochromy.

In combination with sulphur, infusorial earth forms a plastic mass, called zeiodelite, but no uses have yet been made of it.

By far the most important application of infusorial earth in this direction, however, has been successfully accomplished by Mr. Fred. Ransome, of England, in the production on the large scale of an artificial stone for general purposes, to which he has given the name of apoenite. The so-called "Ransome stone," invented by this gentleman, is made by thoroughly incorporating sand and silicate of soda in a mixing mill, moulding into the form required of the block, and then saturating the same with a solution of chloride of calcium, either by exhausting the air with air-pumps, or by forcing the solution through the moulded mass by gravitation or otherwise. The result is the formation of an insoluble silicate of lime, which firmly cements the particles of which the mass is composed, and of chloride of sodium or common salt, which is subsequently removed by the free application of water. The process of washing to remove all traces of the salt from the Ransome stone, which is necessary to prevent its efflorescence and secure its proper cementation, was found to be in many cases so tedious, expensive and objectionable, that the inventor, after many experiments, devised the following process, in which the use of chloride of calcium is avoided. Mr. Ransome mixes suitable quantities of lime (or substances containing lime) and soluble silica (i. e., infusorial earth) with sand, and a solution of silicate of soda or potassa, which, when intimately incorporated, are moulded as before, and allowed to harden gradually, as the silicate of lime, produced by the action of the lime on the silicate of soda, is formed. 
As rapidly as the soda (or potash) of the water-glass solution is set free, it dissolves some of the infusorial silica, and again gives it up to the lime to form more cement, acting thus as the carrier of silica to the lime, until eventually all the lime is combined. In the course of the successive changes that take place, a portion of the free alkali appears to be bound at each step with the lime, as a compound silicate; and as the result of these several changes the whole of the alkali is gradually fixed, thus leaving nothing to be washed out. The mass gradually becomes thoroughly indurated, and in a very short time is converted into a very compact stone-apoenite-capable of withstanding enormous pressure, and increasing in strength and hardness with age.

In combination with magnesite (carbonate of magnesia), infusorial earth forms what is described as an excellent cement, which is manufactured in Germany, and sold under the name of "albolite."

In pottery the infusorial earth has received several important applications. When fused, for example, with borate of lime, as such is obtainable in the trade under the name of boronatrocalcite or tincalzite, an excellent glazing is produced (Manufacturer and Builder), which is not only useful for furnaces and pottery of all kinds, but also for enameling iron and slate, being free from lead and not apt to crack off. By fusing a mixture of infusorial earth (freed from sand) with borate of magnesia (stassfurtite), a kind of "hot-cast porcelain" is produced, having great durability and beauty. For this purpose the infusorial earth requires to be perfectly dry and free from lumps. It is introduced into the crucible in small portions and under constant stirring, until the fused stassfurtite ceases to take up more. The mass may be cast like glass, and if very liquid it may even be blown, and is thus fitted for an extensive application (ibid.).

Bœttger publishes the observation that when an alcoholic solution of any of the coal-tar colors is mixed with a sufficient quantity of infusorial earth, water added, and the mixture filtered, the liquid will run off clear, while the earth retains all the pigment. Hitherto the compounds of alumina have been used for the production of the so-called lakes, and it is quite probable that the above noted behavior of this material may find important applications in the arts.

The use of infusorial earth has been suggested in glass making as a substitute for sand; but it appears not to be well suited for this 
purpose, the reason assigned being that it swells too much in the crucible. In the manufacture of soluble glass (water glass), for which it has likewise been tried, the impurities it contains-clay, phosphate of lime, etc.- have been found to render it somewhat unsuitable.

To conclude a sketch which bas unwittingly taken considerable proportions, the following enumeration will suffice to show that the subject is by no means exhausted: A compound called diatite, devised by Merrick, consists of gum-lac and infusorial earth. The siliceous earth has been added to sealing-wax to prevent its running.; it is sometimes added to paper to give it body; and to soap for the same purpose, and to add to its detergent qualities (?); and it is said to form an excellent addition to rubber, for certain uses of the latter; its addition to modeling clay is said to prevent it from cracking in moulding; and lastly, though doubtless many real or suggested applications of this curious substance have been overlooked, it is said to be of use in the manufacture of smalt and ultramarine.

\section{ON THE DEVELOPMENT OF THE CHEMICAL ARTS}

DURING THE LAST TEN YEARS.*

$$
\text { By DR.A. W. HOFMAN. }
$$

From the Chemical News.

[Continued from Vol. cii, page 360.]

It has been observed that when iron apparatus is employed for generating and conducting the hydrochloric acid gas this conveys along a certain quantity of ferric chloride, from which it cannot be freed before entering the decomposing furnace. Here the iron is deposited either as chloride, or, if the formation of chlorine has already begun, i.e., as soon as watery vapor is mixed with the gases, as pulverulent oxide of iron upon the copper-sulphate. This iron dust falls from the vertical drain-pipes through the grating into the space below, whence it is easily removed. It may here, however, be remarked that Deacon, according to private communications, has latterly omitted the partition walls from the decomposition furnace, by which he effects a more

* "Berichte über die Entwickelung der Chemischen Industrie Während des Letzten Jahrzehends." 